\title{
Partisipasi Masyarakat Dalam Musrenbang Di Desa Tonrongnge Kecamatan Baranti Kebupaten Sidenreng Rappang
}

\author{
Nabilah \\ Prodi Administrasi Publik. Fakultas Ilmu Sosial dan Ilmu Politik \\ Universitas Muhammadi yah Sidenreng Rappang \\ Email: nabilah43182050@gmail.com
}

\begin{abstract}
ABSTRAK
Tujuan penelitian untuk mengetahui partisipasi masyarakat desa dalam penyusuan rencana pembangunan desa Tonrongnge dapat menjadi salah satu tolak ukur sejauh mana desa tersebut mengembangkan nilai-nilai tata kelola pemerintahan desa yang baik dalam roda pemerintahanya. Partisipasi masyarakat dalam Musyawarah Perencanaan Pembangunan (Musrenbang) di Desa Tonrongnge Kecamatan Baranti Kabupaten Sidenreng Rappang. Jenis pengumpulan data ini adalah metode deskriptif dengan pendekatan kualitatif. Populasi penelitian ini adalah seluruh masyarakat di Desa Tonrongnge Kecamatan Baranti Kabupaten Sidenreng Rappang dan sampel yaitu masyarakat yang dianggap banyak mengetahui terhadap masalah yang dihadapi dan diharapkan agar responden yang dipilih mewakili populasi yaitu 94 orang. Penelitihan ini menunjukkan bahwa Pastisipasi Musyawarah Dalam Perencanaan Pembangunan (Musrenbang) di Desa Tonrongnge Kecamatan Baranti Kabupaten Sidenreng Rappang berada pada kategori baik, partisipasi masyarakat dalam musyawarah perencanaan pembangunan berada pada kategori sangat baik, dan Faktor-faktor yang mempengaruhi peranan pemerintah desa dan partisipasi masyarakat dalam Musyawarah Perencanaan Pembangunan berada pada kategori baik .
\end{abstract}

\section{Kata Kunci : Partisipasi Masyarakat;Musrenbang}

\begin{abstract}
ABSTRAK
The purpose of the study to determine the participation of the village community in the preparation of the Tonrongnge village development plan can be one of the benchmarks for the extent to which the village develops the values of good village governance in the wheels of government. Community participation in the Development Planning Deliberation (Musrenbang) in Tonrongnge Village, Baranti District, Sidenreng Rappang Regency. This type of data collection is a descriptive method with a qualitative approach. The population of this research is all people in Tonrongnge Village, Baranti District, Sidenreng Rappang Regency and the sample is people who are considered to know a lot about the problems they face and it is hoped that the selected respondents represent the population, namely 94 people. This research shows that Participation of Deliberations in Development Planning (Musrenbang) in Tonrongnge Village, Baranti District, Sidenreng Rappang Regency is in the good category, community participation in development planning deliberation is in the very
\end{abstract}


good category, and the factors that influence the role of village government and community participation in The Development Planning Conference is in the good category.

\section{Keywords: Community Participation; Musrenbang}

\section{PENDAHULUAN}

Keterlibatan masyarakat dalam proses pembuatan kebijakan pembangunan diatur secara bertahap, hal ini menunjukkan bahwa proses penyusunan kebijakan pembangunan bersifat partisipatif, dimana pemerintah yang menjadi penentu kebijakan pembangunan, sedangkan masyarakat berperan memberikan masukan kepada pemerintah tentang apa yang dibutuhkan oleh masyarakat. Salah satu aplikasinya melalui Forum Musyawarah Perencanaan Pembangunan (Musrenbang) yang dilaksanakan secara berjenjang mulai dari tingkat Desa/Kelurahan, Kecamatan, Kabupaten/Kota, Provinsi, regional/wilayah dan Pusat. Forum musyawarah ini merupakan media yang cukup efektif untuk menampung aspirasi masyarakat yang sekaligus juga menjadi media pemberdayaan dan partisipasi masyarakat selaku subjek dan objek dalam proses pembangunan(Salangka, 2004).

Musyawarah Perencanaan dan Pembangunan (Musrenbang) adalah perencanaan pembangunan yang berusaha mempertemukan aspirasi masyarakat dari bawah dengan usulan program pembangunan dari instansi pemerintah. Musrenbang tercantum dalam dalam beberapa undang-undang dan perda terkait dengan pencanaan pembangunan daerah. Musrenbang merupakan hal yang penting untuk membawa para pemangku kepentingan memahami isu-isu dan permasalahan-permasalahan untuk kesepakatan atas prioritas pembangunan,dan konsesus untuk pemecahan berbagai pembangunan. Musrenbang juga merupakan mensinkronisasikan pendekatan "top Down" dengan "bottom up" pendekatan penilaian kebutuhan masyarakat dengan penilaian yang bersifat teknis, resolusi konflik atas berbagai kepentingan pemerintah dan diluar pemerintah untuk pembangunan daerah, antara kebutuhan program pembangunan dengan kemampuan dan kendala pendanaan, dan wahana untuk mensinergikan berbagai sumber pendanaan pembangunan. Pemerintah perlu mengoptimalisasi pemanfaatan kemajuan teknologi informasi untuk membangun jaringan sistem informasi manajemen dan proses kerja yang memungkinkan pemerintahan bekerja secara terpadu dengan menyederhanakan akses antar unit kerja. Wilkinson et al., (2000) mengatakan pemanfaatan teknologi informasi mencakup adanya (a) pengolahan data, pengolahan informasi, sistem manajemen dan proses kerja secara elektronik(Akhmad, Mustanir, \& Ramadhan, 2006).

Pembangunan nasional dan daerah merupakan bagian yang tidak dapat dipisahkan dari kegiatan pembangunan desa. Desa merupakan basis kekuatan social ekonomi dan politik yang perlu mendapat perhatian serius dari pemerintah. Perencanaan pembangunan selama ini menjadikan masyarakat desa sebagai obyek pembangunan bukan sebagai subyek pembangunan(Ahmad Mustanir1), Kamaruddin Sellang2), Akhwan Ali3), Madaling4) \& 1), 2018).

Lahirnya Undang-Undang Nomor 23 Tahun 2014 tentang Pemerintahan Daerah membuat kebijakan tentang desa dalam memberi pelayanan, peningkatan peran serta dan pemberdayaan masyarakat desa yang ditujukan bagi kesejahteraan masyarakat(Ahmad Mustanir1), Kamaruddin Sellang2), Akhwan Ali3), Madaling4) \& 1), 2018). 
Pelaksanaan perencanaan pembangunan Desa Tonrongnge yang didalamnya termasuk penyusunan program pembangunan dimana masyarakat peran konsolidasi partisipasi, agregasi kepentingan, menyampaikan preferensi, memilih wakil, monitoring dan evaluasi pelaksanaan hasil musrenbang. Pemerintah desa berperan dalam penyediaan suatu informasi, memberikan asistensi teknis, dan pelaksanaan monitoring dan evaluasi, adapun BPD (Badan Permusyawaratan Desa) berperan dalam penjaringan aspirasi dan pengawasan. Partisipasi masyarakat desa dalam penyusunan rencana pembangunan desa tonrongnge dapat menjadi salah satu tolak ukur sejauh mana desa tersebut mengembangkan nilai-nilai tata kelola pemerintahan desa yang baik dalam roda pemerintahannya. Keterlibatan masyarakat desa dalam arti luas harus didorong baik melalui regulasi maupun penciptaan iklim demokratisasi yang ideal di desa. Dengan demikian, akan semakin tumbuh rasa dari masyarakat terhadap program-program desa tersebut.

Partispasi masyarakat merupakan suatu proses yangdapat mendukung masyarakat untuk mulai "sadar" akan situasi dan masalah yang dihadapinya serta berupaya mencari jalan keluar yangdapat dipakai untuk mengatasi masalah mereka (memiliki kesadaran kritis). Sumardi (2010:46), mengemukakan bahwa partisipasi adlah peran serta seseorang atau kelompok masyarakat dalam proses pembangunan baik dalam bentuk pernyataan maupun dalam bentuk kegiatan dengan memberi masukan pikiran, tenaga, waktu, keahlian, modal, dan atau materi, serta ikut memanfaatkan dan menikmati hasil-hasil pembangunan(Zhilviana Sulaeman, Ahmad Mustanir, 2019).

Jika memperhatikan indikator syarat keberhasilan Musrenbang berdasarkan Keputusan Menteri Dalam Negeri No.050-187/Kep/Bangda/2007 tentang Pedoman Penilaian dan Evaluasi Pelaksanaan Penyelenggaraan Musyawarah Perencanaan Pembangunan (Musrenbang), jelas dinyatakan bahwa informasi merupakan indikator penting dalam upaya meningkatkan partisipasi masyarakat. Disebutkan bahwa informasi yang harus ada adalah informasi yang perlu disediakan untuk mendukung penyelenggaraan musrenbang. Informasi ini harus disampaikan jauh sebelum waktu pelaksanaan musrenbang agar stakeholder dapat mempelajari dan merencanakan pertanyaan yang perlu diajukan; informasi mesti sedemikian rupa sehingga mudah dipahami dan sesuai dengan tingkat pengetahuan stakeholders. Informasi juga sejauh mungkin berbentuk visual sehingga mudah dipahami(Salangka, 2004).

\section{TINJAUAN PUSTAKA}

\section{- Konsep Partsipasi Masyarakat}

Warsito (2007:25) mendefenisikan: partisipasi merupakan kesediaan untuk membantu berhasilnya setiap program sesuai dengan kemampuan setiap orang tanpa berarti mengorbankan kepentingan diri sendiri. Sinaga (2005:61) menyebutkan partisipasi antara sesama warga atau anggota suatu perkumpulan dengan partisipasi horizontal, dan partisipasi yang dilakukan oleh bawahan dengan atasan, antar klien dengan patron, atau antara masyarakat sebagai keseluruhan pemerintah, dengan partisipasi vertikal. Keterlibatan dalam berbagai kegiatan politik seperti pemberian suara dalam pemilihan, kampanye dan lain sebagainya, disebut partisipasi dalam proses politik, sedangkan keterlibatan dalam kegiatan seperti perencanaan dan pelaksanaan pembangunan disebut partisipasi dalam proses administratif. Sementara itu keterlibatan masyarakat sebagai suatu kesatuan disebut dengan partisipasi kolektif, sedangkan keterlibatan individual dalam kegiatan kelompok disebut partisipasi individual. Partisipasi vertikal terjadi dalam kondisi tertentu masyarakat yang terlibat atau yang mengambil bagian dalam suatu program dengan pihak lain. Dalam 
hubungan dimana masyarakat berada pada posisi sebagai bawahan, pengikut atau klien. Partisipasi horizontal antara satu dengan yang lain, baik dalam melakukan usaha bersama, maupun dalam rangka melakukan kegiatan dengan pihak lain. Jika masyarakat desa yang bersangkutan tidak berkesempatan berpartisipasi dalam pembangunan suatu proyek di desanya, proyek tersebut pada hakikatnya bukanlah proyek pembangunan desa(Salangka, 2004).

Pengertian partisipasi masyarakat mengemukakan tentang lingkup partisipasi dengan bertolak pada urutan proses perencanaan pembangunan, maka secara rinci jenis partisipasi masyarakat dalam pembangunan sebagai berikut: 1) Partisipasi dalam pengambilan keputusan, 2) Partisipasi dalam pelaksanaan kegiatan, 3) Partisipasi dalam pemantauan dan evaluasi pembangunan, 4) Partisipasi dalam pemanfaatan hasil-hasil pembangunan(Mustanir \& Razak, 2017).

Selanjutnya menurut Adisasmita (2006:41) Partisipasi Masyarakat adalah pemberdayaan masyarakat, peran sertanya dalam kegiatan penyusunan perencanaan implementasi program/proyek pembangunan, dan merupakan aktualisasi dan kesediaan dan kemauan masyarakat untuk berkorban dan berkontribusi terhadap implementasi Program Pembangunan(Mustanir \& Yasin, 2018).

Menurut Adisasmita (2006 :34) Partisipasi anggota masyarakat adalah keterlibatan anggota masyarakat dalam pembangunan, meliputi kegiatan dalam perencanaan dan pelaksanaan (implementasi) program/proyek pembangunan yang dikerjakan di dalam masyarakat. Sedangkan menurut Slamet sebagaimana dikutip oleh Suryono (2001:124) Partisipasi masyarakat dalam pembangunan diartikan sebagai ikut serta masyarakat dalam pembangunan, ikut dalam kegiatan pembangunan dan ikut serta pemanfaatan dan menikmati hasil-hasil pembangunan(Mustanir \& Yasin, 2018).

Partisipasi Masyarakat. Didalam melaksakanan suatu program atau pun suatu badan usaha sangat dibutuhkan pasrtisipasi masyarakat didalam nya agar semua program yang telah di rencakan oleh suatu organisasi bisa berjalan sebagaimana mestinya, selain partisipsi kondisi masyarakat juga sangat berpengaruh didalam keberhasilan program yang telah di rencanakan(Mustanir \& Adnan, 2020).

Pada pengelolaan pembangunan pada dasarnya dimulai dari tahap perencanaan, pelaksanaan, pengendalian atau pembinaan, sampai dengan pemeliharaan dan tindak lanjut hasil-hasil pembangunan. Inilah yang disebut sebagai fungsi pengelolaan pembangunan secara utuh. Mengingat sifat pengelolaan pembangunan desa/kelurahan itu meliputi banyak aspek dan memiliki keterkaitan dengan banyak pihak, maka tidak dapat dihindari bila mana metode perencanaan partisipatif yang diperkenalkan di tingkat desa/kelurahan juga banyak jenisnya:

1. Dengan penggunaan berbagai alternatif partisipasi masyarakat itu sendiri, maka manfaat yang dapat diperoleh antara lain: Terjadi dialog dua arah antara pemerintah dan masyarakat.

2. Lingkungan dan budaya lokal dinilai sebagai sumber daya pembangunan.

3. Dapat mengurangi konflik kepentingan dan konflik sosial.

4. Percaya diri dan semangat membangun para aparat pemerintah dan masyarakat semakin meningkat.

5. Masyarakat menjadi lebih aktif dan dinamis.

6. Inisiatif masyarakat terus tumbuh tanpa dipaksakan. 
7. Pemerintah maupun maupun masyarakat merasakan bahwa keputusan terbaik adalah bila melibatkan masyarakat.

\section{- Musyawarah Rencana Pembangunan (Musrembang) Desa}

Musyawarah rencana pembangunan merupakan Perencanaan Pembangunan Bersama Masyarakat adalah panduan atau model pembangunan kelurahan yang menitikberatkan pada peran serta masyarakat dalam keseluruhan proses pembangunan. Pendekatan ini dilandasi oleh nilai-nilai dan semangat gotong-royong yang telah mengakar dalam budaya masyarakat Indonesia. Gotong-royong bertumpu pada keyakinan bahwa setiap warga masyarakat memiliki hak untuk memutuskan dan merencanakan apa yang terbaik bagi diri dan lingkungan serta cara terbaik dalam upaya mewujudkannya. Secara garis besar musyawarah rencana pembangunan mengandung pengertian sebagai berikut: 1) Perencanaan sebagai serangkaian kegiatan analisis mulai dari indentifikasi kebutuhan masyarakat hingga penetapan program pembangunan. 2) Perencanaan pembangunan lingkungan, semua program peningkatan kesejahteraan, ketenteraman, kemakmuran dan perdamaian masyarakat di lingkungan pemukiman dari tingkat RT/RW, dusun dan kelurahan. 3) Perencanaan yang dilaksanakan berdasar pada masalah, kebutuhan, aspirasi dan sumber daya masyarakat sendiri. 4) Terwujud peran serta masyarakat dalam perencanaan pembangunan(Mustanir \& Jaya, 2016).

S. Pradja (26: 2014) dalam menjelaskan pemimpin dan kepemimpinan, ada beberapa hal yang perlu di perhatikan, di antaranya: pertama, kekuasaan dan kewenangan, yaitu kemampuan untuk bertindak bagi seorang pemimpin untuk menggerakkan bawahannya agar mengikuti kehendaknya dalam mencapai tujuan yang telah di tentukan sebelumnya(Mustanir \& Jaya, 2016).

Berkomunikasi yang baik ini adalah keterampilan yang wajib dimiliki oleh setiap pegawai, lantaran hal tadi akan berpengaruh terhadap proses penyelesaian pekerjaan menurut seseorang pegawai. Good governance pada pencapaiannya wajib didukung sang public service menjadi orientasi pada penyelenggaraan pelayanan. Pelayanan publik sebagai bagian krusial pada pencapaian tujuan pemerintahan yang baik(Jamal, Mustanir, \& Latif, 2020).

Perencanaan yang menghasilkan program pembangunan yang diharapkan dapat memberikan dampak terhadap peningkatan kesejahteraan kemakmuran dan perdamaian masyarakat dalam jangka panjang. Musrenbang dapat digunakan sebagai proses bernegosiasi, berekonsiliasi dan berharmonisasi antara pemerintah dan pemangku kepentingan non pemerintah, sekaligus mencapai konsesus bersama mengenai prioritas kegiatan pembangunan(Mustanir \& Razak, 2017).

Salah satu kunci dalam proses Musrenbang desa adalah adanya musyawarah masyarakat dalam merumuskan rencana pembangunan desa. Konsep musyawarah menunjukkan bahwa forum Musrenbang desa bersifat partisipatif dan dialogis. Proses musrenbang desa jangan sampai disusun sebagai suatu acara seremonial yang separuh atau sebagian besar dari waktunya diisi dengan sambutan dan pidato-pidato. Inti dari musrenbang desa adalah partisipasi aktif warga. Dalam Musrembang, pelibatan masyarakat merupakan cerminan dari praktik partisipasi warga dan sekaligus arena akuntabilitas pemerintahan desa.

(Ahmad Mustanir, 2017)Faktor-faktor yang mempengaruhi partisipasi masyarakat dalam musrenbang antara lain adalah : 
- Faktor lingkungan fisik, mencakup; kesuburan tanah, jenis tanah, iklim, topografi dan orbitasi daerah.

- Faktor sosial ekonomi, mencakup; jenis pekerjaan, tingkat pendapatan, tingkat pendidikan, status pemilikan rumah / lahan, jumlah tanggungan keluarga, jumlah tenaga kerja keluarga dan tingkat kesehatan.

- Faktor sosial budaya, mencakup; norma, nilai kepercayaan, pengetahuan, sikap, status pernikahan, usia, jenis kelamin, dan simbol-simbol.

- Faktor policy pemerintah, mencakup; sifat-sifat koordinasi kepemimpinan lembaga sosial, pendekatan untuk memonitor masyarakat dan tingkat kebebasan untuk menyatukan pendapat dan keinginan.

\section{METODE PENELITIAN}

Penelitian ini menggunakan metode deskriptif kualitatif. (Moleong, 2010 : 3) Teknik pengumpulan data yang dilakukan adalah: melalui Penelitian Lapangan dengan cara observasi dan wawancara (Data Primer), Studi kepustakaan/library research (membaca buku, majalah, surat kabar, dokumen-dokumen, dan media informasi lain dan Penelusuran data online yakni menggunakan fasilitas internet (Data Sekunder). Untuk mendapatkan hasil yang obyektif dalam penelitian ini, maka data yang didapatkan dilapangan akan diolah dan dianalisa secara kualitatif, yaitu dengan menggambarkan dan menjelaskan hasil-hasil penelitian dari sejumlah data-data yang telah diperoleh.

\section{PEMBAHASAN}

Musrenbang merupakan forum bagi masyarakat untuk berpatisipasi dalam perumus perencanaan pembangunan yang dimulai dari tingkat Desa/Kelurahan, Kecamatan, Kabupaten/Kota. Pemerintah DesaTonrongnge dalam hal ini telah mengupayakan unyuk pelaksaanaan Musrenbang secara berjenjang yang dimulai dari tingkatan paling bawah sampai kepada tingkatan atas.

Antusias warga pelaksanaan Musrenbang pada tingkat Desa cukup baik dan terlibat langsung dalam pemberian gagasan dan usulan yang diharapkan menjadi agenda pembangunan desa. Secara umum hambatan atau kendala yang dihadapi dalam proses penyelenggaraan Musyawarah Perencanaan pembangunan adalah kurangnya pemahaman masyarakat tentang peserta Musrenbang mengenai Perencanaan Pembangunan dan proses Musrenbang juga belum dipahami sebagian besar peserta karena tidak adanya pemberitahuan secara rinci mengenai bagaimana proses Musrenbang, apa yang akan dibahas dalam Musrenbang, untuk kepentingan pelaksanaan proses perencanaan pembangunan belum diawali dengan kegiatan pendahuluan untuk mendapatkan data yang valid mengenai potensi, masalah dan kebutuhan masyarakat, juga minimnya kegiatan non-fisik yang diusulkan dalam musrenbang, sehingga proses pemberdayaan masyarakat menjadi terhambat serta lambatnya tindak lanjut nyata dari hasil musrenbang. Melihat fenomena yang terjadi pemerintah desa berpandangan bahwa Pemerintah Desa yang paling tepat dalam merumuskan apa yang menjadi rencana dan program pembangunan untuk masyarakat Desa Tonrongnge, dengan alasan karena stakeholders dalam hal ini pemerintah Desa Tonrongnge dengan jajarannya memang betul-betul ahli dan memahami setiap bidang-bidang yang akan dikerjakan. Wewenang Pada umumnya kewenangan harus bersifat formal agar perintah dapat dilaksanakan secara efektif. Kewenangan merupakan otoritas atau legitimasibagipara 
pelaksana dalam melaksanakan kebijakan yang ditetapkan secara politik(Mustanir, 2016). Dalam menjalankan kepemimpinannya dan mencapai tujuan yang diinginkan, maka seorang pemimpin harus memiliki teknik kepemimpinan, karena dengan teknik kepemimpinan itulah yang akan menunjukan bahwa ia mampu untuk memimpin dan merupakan pencerminan jati dirinya sebagai seorang pemimpin(Ahmad Mustanir 1) \& Samad 2), Abdul Jabbar 3), Monalisa Ibrahim 4), 2019).

S. Pradja (26: 2014) dalam menjelaskan pemimpin dan kepemimpinan, ada beberapa hal yang perlu di perhatikan, di antaranya: pertama, kekuasaan dan kewenangan, yaitu kemampuan untuk bertindak bagi seorang pemimpin untuk menggerakkan bawahannya agar mengikuti kehendaknya dalam mencapai tujuan yang telah di tentukan sebelumnya. Kedua, kewibawaan, yaitu berbagai keunggulan yang dimiliki seorang pemimpin, sehingga membedakan dengan yang di pimpinnya, dan dengan keunggulan tersebut, orang lain patuh dan bersedia melakukan kegiatan-kegiatan yang di kehendakinya. Ketiga, kemampuan, yaitu keseluruhan daya, baik berupa keterampilan sosial maupun keterampilan teknis yang melebihi orang lain.

Masyarakat dalam kedudukannya sebagai subyek pembangunan dituntut dalam memberikan sumbangan terhadap apa yang dibutuhkan dalam pembangunan.Kesediaan memberikan sumbangan ini bukan lahir begitu saja, akan tetapi terdorong oleh motivasimotivasi tertentu yang dicapai. Motivasi sangat diperlukan dalam kegiatan/proses belajar, maka tidak akan mungkin melaksanakan kegiatan belajar dengan baik. Oleh karena itu, motivasi diperlukan dalam menentukan kegiatan belajar yang intens bagi para anak didik. Karena motivasi menurut Sardiman (2006) adalah daya penggerak dari dalam untuk melakukan kegiatan untuk mencapai tujuan. Sedangkan partisipasi menurut Newstrom (2004) adalah keterlibatan mental dan emosional dari orang dalam situasi kelompok(Mustanir, Dema, Syarifuddin, Meity, \& Wulandari, 2018).

Pelaksanaan Musrenbang yang berjenjang mulai dari tingkat desa/kelurahan, kecematan, kabupaten/kota, propinsi, hingga dibawa ke tingkat nasional merupakan kesempatan emas bagi masyarakat untuk dapat terlibat perencanaan pembangunan. Akan tetapi dalam penyelenggaraannya kerap kurang memperhatikan aspek partisipasi secara luas, dan masih terbatas pada seremonial dan acara rutin belaka. Peran lembaga daerah dalam hal ini pemerintah daerah dan dewan Perwakilan Rakyat Daerah (DPRD) untuk meningkatkan partisipasi masyarakat khususnya dalam forum Musrenbang mutlak diperlukan sebagai salah satu usaha menuju pemerintahan daerah yang lebih baik(Ahmad Mustanir1), Kamaruddin Sellang2), Akhwan Ali3), Madaling4) \& 1), 2018).

Pelaksanaan perencanaan pembangunan Desa Malola yang melibatkan Musrenbang dalam rangka penyusunan Program Desa hingga pendanaan dalam APBDes, memenuhi tiga prinsip seperti yang dikemukakan oleh Martini (2012:97) sebagai berikut:

- Prinsip Partisipatif (Participative) Prinsip partisipatif menunjukkan bahwa rakyat atau masyarakat yang akan diuntungkan oleh (atau memperoleh manfaat dari) perencanaan harus turut serta dalam prosesnya. Dengan kata lain masyarakat menikmati faedah perencanaan bukan semata-mata dari hasil perencanaan, tetapi dari keikutsertaan dalam prosesnya.

- Prinsip Rensponsif Prinsip ini menunjukkan bahwa perencanaan kegiatan yang dilaksanakan dan dihasilkan disebabkan adanya merespon apa yang terjadi dan isu yang berkembang di tengah masyarakat. 
- Prinsip Keseluruhan (Holistic) Prinsip ini menunjukkan bahwa masalah dalam perencanaan pelaksanaannya tidak dapat hanya dilihat dari satu sisi atau unsur tetapi harus dilihat dari berbagai aspek dan dalam keutuhan konsep secara keseluruhan. Dalam konsep tersebut/ unsur yang dikehendaki selain harus mencakup hal-hal di atas juga mengandung unsur yang dapat berkembang secara terbuka dan demokratis.

\section{KESIMPULAN}

Pelaksanaan Musrenbang Desa Tonrongnge telah dilaksanakan secara optimal, berdasarkan aspek yang dikaji pada penelitian ini adalah sebagai berikut: Dari Prinsip partisipatif, menunjukkan bahwa rakyat atau masyarakat yang akan diuntungkan oleh (atau memperoleh manfaat dari) perencanaan harus turut serta dalam prosesnya. Dengan kata lain masyarakat menikmati faedah perencanaan bukan semata-mata dari hasil perencanaan, tetapi dari keikutsertaan dalam prosesnya, Prinsip Rensponsif Prinsip ini menunjukkan bahwa perencanaan kegiatan yang dilaksanakan dan dihasilkan disebabkan adanya merespon apa yang terjadi dan isu yang berkembang di tengah masyaraka, Prinsip Keseluruhan (Holistic) Prinsip ini menunjukkan bahwa masalah dalam perencanaan pelaksanaannya tidak dapat hanya dilihat dari satu sisi atau unsur tetapi harus dilihat dari berbagai aspek dan dalam keutuhan konsep secara keseluruhan. Dalam konsep tersebut/ unsur yang dikehendaki selain harus mencakup hal-hal di atas juga mengandung unsur yang dapat berkembang secara terbuka dan demokratis.

Pelaksanaan Musrenbang di Desa Tonrongnge untuk kedepannya perlu memperhatikan aspek partisipatif demokratis, yaitu dengan mengakomodir seluruh masyarakat desa agar dapat ikuti serta dalam kegiatan musrenbang, apabila menjadi kendala keterbatasan sarana dan prasarana, dapat dilakukan musyawarah di tingkat jaga (dusun) setelah itu dapat dibawa ke tingkat desa. Untuk ketepatan dan efektifitas prioritas program dalam Musrenbang, pemerintah desa sehingga diharapkan dapat mendengarkan aspirasi masyarakat mengenai kebutuhan pokoknya dan perlu diadakan pengukuran kepuasan dari masyarakat mengenai kinerja pemerintah dalam pembangunan melalui evaluasi dan laporan kinerja.

\section{DAFTAR PUSTAKA}

Ahmad Mustanir 1), Z., \& Samad 2), Abdul Jabbar 3), Monalisa Ibrahim 4), J. 5. (2019). KEPEMIMPINAN LURAH TERHADAP PEMBERDAYAAN MASYARAKAT DI KELURAHAN LAUTANG BENTENG KABUPATEN SIDENRENG RAPPANG. Journal of Social Politics and Governance, 1(2), 20-39.

Ahmad Mustanir, P. A. (2017). Partisipasi masyarakat dalam musyawarah rencana pembangunan di kelurahan kanyuara kecamatan watang sidenreng kabupaten sidenreng rappang. Jurnal Politik Profetik, 5(2), 248-261.

Ahmad Mustanir1), Kamaruddin Sellang2), Akhwan Ali3), Madaling4), M., \& 1). (2018). PERANAN APARATUR PEMERINTAH DESA DAN PARTISIPASI MASYARAKAT DALAM MUSYAWARAH PERENCANAAN PEMBANGUNAN DI DESA TONRONGNGE KECAMATAN BARANTI KABUPATEN SIDENRENG RAPPANG. Jurnal Ilmiah Clean Government, 2(1), 67-84.

Akhmad, I., Mustanir, A., \& Ramadhan, M. R. (2006). PENGARUH PEMANFAATAN 
TEKHNOLOGI INFORMASI DAN PENGAWASAN KEUANGAN DAERAH TERHADAP KUALITAS LAPORAN KEUANGAN KABUPATEN ENREKANG. Prosiding Konferensi Nasional, 23 - 25(Maret 2018), 89-103.

Jamal, Y., Mustanir, A., \& Latif, A. (2020). Penerapan prinsip good governance terhadap aparatur desa dalam pelayanan publik di desa ciro-ciroe kecamatan watang pulu kabupaten sidenreng rappang. PRAJA, 8(3), 207-212.

Mustanir, A. (2016). Implementasi kebijakan dan efektivitas pengelolaan terhadap penerimaan retribusi di pasar lancirang kecamatan pitu riawa kabupaten sidenreng rappang. Jurnal Ilmiah, 13(3), 542-558.

Mustanir, A., \& Adnan, A. A. (2020). PENGARUH MANAJEMEN PENGELOLAAN BADAN USAHA MILIK DESA TERHADAP PENINGKATAN PARTISIPASI MASYARAKAT DI DESA BILA RIASE KECAMATAN PITU RIASE KEBUPATEN SIDENRENG RAPPANG. Movere Journal, 2(2), 56-65.

Mustanir, A., Dema, H., Syarifuddin, H., Meity, K., \& Wulandari, S. (2018). Pengaruh Motivasi dan Partisipasi Masyarakat terhadap Pembangunan di Kelurahan Lalebata Kecamatan Panca Rijang Kabupaten Sidenreng Rappang. Jurnal Ilmiah Clean Government (JCG), 2(1), 27-39. Retrieved from http://lonsuit.unismuhluwuk.ac.id/index.php/clean/article/view/212

Mustanir, A., \& Jaya, I. (2016). Pengaruh kepemimpinan dan budaya politik terhadap perilaku pemilih towani tolotang di kecamatan maritengngae kabupaten sidenreng rappang. Jurnal Politik Profetik, 04(1), 85-97.

Mustanir, A., \& Razak, M. R. R. (2017). Nilai Sosial Budaya Pada Partisipasi Masyarakat Etnik Towani Tolotang Dalam Musyawarah Rencana Pembangunan. Prosiding Konferensi NasionaL, 6(September), 1-7.

Mustanir, A., \& Yasin, A. (2018). Transect Pada Perencanaan Pembangunan Partisipatif. Jurnal Ilmiah Ilmu Administrasi Publik, 8(2), 21-31.

Salangka, W. P. R. (2004). Partisipasi masyarakat dalam musrenbang di desa malola kecamatan kumelembuai kabupaten minahasa selatan.

Zhilviana Sulaeman, Ahmad Mustanir, A. I. M. (2019). Partisipasi masyarakat terhadap perwujudan good governance di desa damai kecamatan watang sidenreng kabupaten sidenreng rappang. Praja,7(3), 88-92. 